NBER WORKING PAPER SERIES

\title{
THE 2021 PAYCHECK PROTECTION PROGRAM REBOOT: \\ LOAN DISBURSEMENT TO EMPLOYER AND \\ NONEMPLOYER BUSINESSES IN MINORITY COMMUNITIES
}

\author{
Robert W. Fairlie \\ Frank Fossen \\ Working Paper 29732 \\ http://www.nber.org/papers/w29732 \\ NATIONAL BUREAU OF ECONOMIC RESEARCH \\ 1050 Massachusetts Avenue \\ Cambridge, MA 02138 \\ February 2022
}

We would like to thank Karen Mills, Javier Miranda, and participants at the AEA Meetings, NBER Entrepreneurship Workshop, the PPIC California labor market workshop, the Kauffman Foundation Entrepreneurship Issue Forum, Axios/Google Small Business Matters Expert Panel, and JPMorgan Chase Institute Data Dialogue meetings for comments and suggestions. The research project has also benefited from numerous conversations with the press and policymakers. An initial analysis of the third (2021) round of the PPP was prepared for the U.S. Senate Committee on Small Business and Entrepreneurship. Special thanks go to Zach Mider, Jason Grotto and Cedric Sam for discussions of the data and analysis. We also thank Gagandeep Sachdeva for research assistance. The authors did not receive funding for this research project and have no disclosures. The views expressed herein are those of the authors and do not necessarily reflect the views of the National Bureau of Economic Research.

NBER working papers are circulated for discussion and comment purposes. They have not been peer-reviewed or been subject to the review by the NBER Board of Directors that accompanies official NBER publications.

(C) 2022 by Robert W. Fairlie and Frank Fossen. All rights reserved. Short sections of text, not to exceed two paragraphs, may be quoted without explicit permission provided that full credit, including $\odot$ notice, is given to the source. 
The 2021 Paycheck Protection Program Reboot: Loan Disbursement to Employer and Nonemployer Businesses in Minority Communities

Robert W. Fairlie and Frank Fossen

NBER Working Paper No. 29732

February 2022

JEL No. J15,L26

\begin{abstract}
Was the $\$ 278$ billion reboot of the $\$ 800$ billion Paycheck Protection Program (PPP) in early 2021 disbursed equitably to minority communities? This paper provides the first analysis of how PPP funds were disbursed to minority communities in the third and final round of the program, which was specifically targeted to underserved and disadvantaged communities. Using administrative microdata on the universe of PPP loans, we find a strong positive relationship between PPP flows, as measured by the number of loans per employer business or loan amounts per employee, and the minority share of the population or businesses in the third round. In contrast, the relationship was negative in the first round of 2020 and less positive in the second round of 2020. We find a stronger positive relationship between minority share and loan numbers or amounts to employer businesses for first draw loans than second draw loans in 2021 (capturing some persistence in inequities). The patterns are similar for loan numbers and amounts to nonemployer businesses but with a strong positive relationship with minority share for both first draw and second draw loans. The rebooted PPP that ran from January to May 2021 appears to have been disbursed to minority communities as intended.
\end{abstract}

Robert W. Fairlie

Department of Economics

Engineering 2 Building

University of California at Santa Cruz

Santa Cruz, CA 95064

and NBER

rfairlie@ucsc.edu

Frank Fossen

1664 N. Virginia Street

Department of Economics

College of Business

Reno, NV 89557-0030

United States

ffossen@unr.edu 


\section{Introduction}

The economic impacts of the pandemic have been especially severe for small businesses, workers, and communities of color (Couch et al. 2020; Cowan 2020; Fairlie 2020; Montenovo et al. 2020). Anticipating these potential losses, one of the stated goals in the \$2.2 trillion CARES Act passed into law on March 27, 2020 was to prioritize serving “underserved markets” and businesses owned by “socially and economically disadvantaged individuals” (U.S. Congress 2020). In the beginning of the pandemic, however, minority businesses and communities were generally delayed in obtaining financial assistance through a key component of the CARES Act, the Paycheck Protection Program (PPP) (Grotto, et al. 2020). The initial Paycheck Protection Program (PPP) was designed to provide loans to small businesses to keep them afloat and retain their employees. Loan amounts were intended to equal 2.5 months of average payroll costs, and could be forgiven if the business retained its employees on the payroll. The first round of the PPP provided $\$ 342$ billion through 1.7 million loans with disproportionately less going to minority communities (Grotto et al. 2020; Fairlie and Fossen 2021).

As the pandemic continued and the negative economic impacts became increasingly clear, Congress appropriated additional funds and the PPP started up again on April 27, 2020. In this second round of PPP funding, as shown in Table 1, fintech lenders such as Cross River Bank, Customers Bank, BSD Capital, Kabbage, Itria Ventures, Celtic Bank and WebBank were more involved in making loans, and disbursement to minority businesses and communities improved (Grotto et al. 2020; Fei and Yang, 2021). ${ }^{1}$ The second round which ran until August 8, 2020 provided $\$ 189$ billion through 2.6 million loans to small businesses.

\footnotetext{
${ }^{1}$ See Fairlie and Fossen (2021) for an analysis of disbursement of Economic Injury Disaster Loan Program (EIDL) funds to minority communities. The EIDL program, which is also administered by the SBA, is designed to provide either loans or advances to small businesses that are losing revenues and sales due to COVID-19. Nearly 3.6 EIDL
} 
A few months after the PPP ended in summer 2020, COVID cases began to rise rapidly and social-distancing restrictions returned. New COVID cases rose from 1.2 million in September 2020 to 6.4 million in December 2020 and 6.1 million in January 2021 (Centers for Disease Control and Prevention 2021). Given these concerns the PPP restarted in January 2021 with a strong emphasis on helping eligible borrowers in underserved and disadvantaged communities. To promote access for smaller lenders and their customers, the SBA restricted the program which included a head start for applications through Community Development Financial Institutions (CDFI) before more broadly opening up the program, and a two-week exclusivity application period for businesses with fewer than 20 employees in February 2021. Part of the funds were set aside for low- or moderate-income businesses, and some exclusionary restrictions were eliminated (U.S. Small Business Administration 2021). Another major change was that the PPP opened up to allow small businesses that continued to struggle in the pandemic to obtain a second loan. During this third round of the PPP from January to May 2021, a total of \$278 billion through 6.7 million loans was provided of which $\$ 209$ billion and 2.9 million loans were second draw loans. At this stage of the pandemic, PPP loans were focused more on sole proprietors, self-employed individuals, and independent contractors without employees than employer businesses with an emphasis on helping to preserve the owner's job.

Did PPP funds in the rebooted program in 2021 get disproportionately disbursed to minority communities as intended or did the program struggle with equitable loan disbursement? How did the disbursement of second draw loans compare to first loan draws? Demand for second draw loans is likely to be higher in disadvantaged communities as small business continued to struggle, and major structural changes to the program are likely to have increased the supply of

loans for \$200 billion and nearly 5.8 million EIDL advances for \$20 billion were provided to small businesses in 2020. 
loans to those same communities, but second draw loan receipt is conditional on receiving a loan in one of the first two rounds. Did disbursement to minority communities differ between loans to small businesses with employees and loans to businesses without employees (nonemployers), which were increasingly targeted in 2021? Equitable disbursement of employer business loans has implications for community impacts on not only owners but also jobs and broader economic activity, while equitable loans to nonemployer businesses also has important implications for the owner. Finally, how does first loan disbursement across minority communities in the third round compare with disbursement in the earlier first loan draw rounds in the pandemic? This paper provides the first exploration of these important unanswered questions. We use administrative microdata covering the universe of PPP loans to small businesses. We also use newly available information on first vs second draw loans and newly available information on exact loan amounts for larger loans.

Our analysis reveals a strong positive relationship between PPP flows, as measured by the number of loans per employer business or loan amounts per employee, and the minority share of the population or businesses in the third round. We find a stronger positive relationship between minority share and loan numbers or amounts to employer businesses for first draw loans than second draw loans in 2021 (capturing some persistence in inequities). The patterns are similar for loan numbers and amounts to nonemployer businesses but with a strong positive relationship with minority share for both first draw and second draw loans. In contrast to these findings, we find a negative relationship in the first round of 2020 and a less positive relationship in the second round of 2020 for both employer and nonemployer businesses. The rebooted PPP that ran from January to May 2021 and provided \$278 billion in funds to small businesses appears to have been disbursed to minority communities as intended. 


\section{Data}

We use loan-level PPP microdata provided by the U.S. Small Business Administration (SBA). The PPP data cover the universe of loans provided through the program, which was from April 3, 2020 to June 30, 2021. Over the entire program, 11.8 million loans were approved for a total of $\$ 800$ billion.

The loan microdata include information on the amount of the loan. In the first release of data for larger loans, only ranges were reported (\$150,000-350,000, \$350,000-1 million, \$1-2 million, \$2-5 million, and \$5-10 million). But, this restriction was later lifted and exact loan amounts are now available for all PPP loans. Exact addresses, including the zip code, and even the name of the business is provided for all PPP loans. The data also include information on industry, business type, jobs retained self-reported by the business, and name of the lender. The top lender providing PPP loans was Prestamos, a nonprofit CDFI which was especially active in 2021 (see Table 1).

Information on the race, ethnicity, gender and veteran status of the owner is incomplete. Some versions of the application form include questions to optionally self-report demographic information on the owners ${ }^{2}$ while others ${ }^{3}$ relied on banks to report the information. The result is that 70 percent of loans provide neither race nor ethnicity information, and those that have information are heavily correlated with zip code and owner characteristics indicating that missingness is likely to be non-random. ${ }^{4}$ Recently, a couple of alternative approaches have been

\footnotetext{
${ }^{2}$ https://www.sba.gov/sites/default/files/2021-03/BorrowerApplication2483ARPrevisions\%20\%28final\%203-1821\%29-508.pdf.

${ }^{3}$ https://www.sba.gov/sites/default/files/2020-07/PPP-Borrower-Application-Form-508.pdf.

${ }^{4}$ Noting these concerns Atkins, Cook and Seamans (2021) use different comparison groups with and without missing race information and find that Black-owned businesses received loans that were approximately 50 percent lower than white-owned businesses after controlling for other factors. Darity and Garcia (2022) find evidence of benefits from not reporting race by black-owned businesses on the PPP loan applications.
} 
taken to identify the race of the business owner on the loan. Howell et al. (2021), for example, predict a business owner's race and ethnicity using information such as the owner's name and location. Owner names are obtained from business registrations in collaboration with a data analytics firm. A random forest model trained by using the subset of PPP loans with owner's race information is used to improve prediction accuracy. They note that the assigned race should be viewed as being highly correlated with self-reported race and that it contains important socioeconomic content, consistent with previous research showing discrimination against job applicants with "African American-sounding” names. Fei and Yang (2021) focus on PPP recipients in the Food Services and Drinking Places sector for which they can find a Yelp listing. They proxy for minority-owned businesses based on the food type from yelp.com. Chernenko and Scharfstein (2021) merge race and ethnicity information for owners of restaurants in Florida from voter registration data.

We distinguish between loans to employer businesses and loans to nonemployer businesses. The distinction is relevant because the percent of PPP loans going to independent contractors, self-employment individuals and sole proprietors with no employees increased substantially in 2021. We classify all self-employed individuals and independent contractors as nonemployer businesses as well as sole proprietorships that report only one person working in the business. $^{5}$ All other businesses are classified as employer businesses. We exclude nonprofit businesses (2.3 percent) and businesses with a nonclassifiable industry (0.7 percent) throughout our analysis.

To normalize the number of PPP loans to employer businesses by zip code we calculate loans per employer business. We use data from County Business Patterns (CBP) on business

\footnotetext{
${ }^{5}$ A very small number of sole proprietorships report zero persons, we also classify these as nonemployer businesses.
} 
establishments with employees. The data are provided by the U.S. Census Bureau at the zip code level as well as other geographical levels. The CBP data on employer establishments do not include counts of farms and nonprofits. We acquire farm data by zip code from the U.S. Department of Agriculture’s National Agricultural Statistics Service (NASS).

To normalize loan amounts to employer businesses we calculate average loan amounts per business employee in each zip code. CBP data also includes employment levels for employer business establishments down to the zip code level. The normalization adjusts for loan amount differences due to differences in employment size by location. However, no information on the number of employees from agricultural businesses is available, so we exclude these businesses from the analysis of loan amounts.

Data on the number of nonemployer businesses are unavailable at the zip code level, we therefore analyze loans to nonemployer businesses at the county level. To normalize the number of PPP loans and loan amounts to nonemployer businesses we use the 2018 Nonemployer Statistics (NES) provided by the U.S. Census Bureau. A caveat with this normalization is that the available Census data include all business entities that have annual receipts of at least $\$ 1,000$, file IRS tax forms for sole proprietorships (Form 1040, Schedule C), partnerships (Form 1065), or corporations (the Form 1120 series), and have no paid employees. These data include all consultants, side businesses, hobby businesses, part-time contract or gig work, and other small-scale business activity as long as it produces $\$ 1,000$ or more in annual revenues which are generally ineligible for PPP loans. Based on this very inclusive definition there are roughly 26.8 million nonemployer business entities in the United States.

We compare these measures of loan receipt and loan amounts to data from the Census of Population on the minority share of the population across communities. We measure minority 
share of the population by zip code for employer businesses and by county for nonemployer businesses. In addition to analyzing the relationship between PPP loan receipt per employer business by the minority share of the population we examine the relationship by minority share of employer businesses. We use data from the Annual Business Survey (ABS) on employer businesses at the county level to calculate the minority share of employer businesses in each location. We exclude PPP loans to agricultural businesses here due to a lack of data on the minority status of farmers. Data from the ABS are not available at the zip code level.

Table 2 provides mean values for the main variables of interest, weighted by population in the zip code or county. Across counties, the number of PPP loans to nonemployer businesses per nonemployer business increased substantially from the first round in early 2020 to the third round in 2021 (first draw loans). The weighted average loan amount to nonemployer businesses per nonemployer business (unconditional on receiving a loan) also increased dramatically over this period. In contrast, the number of PPP loans to employer businesses per employer business in zip codes and the unconditional PPP loan amount to employer businesses per employee in zip codes decreased from the first round to the third round. Consistent with second draw loans in Round 3 originating with businesses receiving loans in Rounds 1 or 2, loan numbers and amounts were higher for employer businesses for second draw loans than first draw loans but lower for nonemployer businesses. The minority share of the population across zip codes or counties has a weighted mean of 0.389 and the minority share of employer businesses has a lower weighted mean of 0.180 reflecting substantially lower business ownership rates among minorities.

The distribution of PPP loan amounts appears in Table 3, separately for employer and nonemployer businesses. ${ }^{6}$ For employer businesses loans in the first round in early 2020 were

\footnotetext{
${ }^{6}$ Appendix Table A1 reports the combined distribution of all PPP loans.
} 
generally substantially larger than in later rounds consistent with large banks providing loans to their experienced small business clients in the first round (Table 1). The pattern across rounds is different for nonemployer businesses. For nonemployer businesses, median loans were largest in the third round in 2021 when the PPP was rebooted with a different emphasis.

\section{Results}

In this section we analyze how PPP loan receipt was distributed across minority communities. We present results for employer businesses first and then turn to nonemployer businesses, in each case analyzing both loan numbers and loan amounts per business in the zip code or county. We always start with the most recent data for the third round in 2021, which has not been analyzed before, and then compare with results for the first two rounds in 2020.

The following column charts show mean normalized numbers of loans or loan amounts in zip codes or counties in bins of minority shares of 5 percentage points, weighted by the population in the zip code or county. ${ }^{7}$ The figures also include plotted weighted quadratic regression curves to help show the relationship. The double arrow on each Y-axis indicates the range of half a standard deviation from the median across zip codes or counties to provide a sense of relative scale of the relationships.

Before discussing the results, two important points are noted. First, we do not report confidence intervals (i.e. "whiskers”) because we use the universe of PPP loans and administrative data based on the Census Business Register. Second, we focus on the raw relationship between PPP loan receipt and minority share of the population without controlling for other factors because we are trying to capture the influences of these neighborhood characteristics. For example, if

\footnotetext{
${ }^{7}$ Unweighted charts show the same patterns and are available from the authors on request.
} 
minority communities have higher poverty rates and that is correlated with receipt of PPP loans then we want to include that in our measurement (not control for it). Even if the driver of loan receipt is income it is reflected in race and that is what we are trying to capture.

\subsection{Employer Businesses}

We begin with PPP loan receipt per employer business by minority share of the population at the zip code level. Figure 1 displays the relationship in the third round of the PPP in 2021 for the first draw of a PPP loan (Panel A) and the second draw for businesses that had received a PPP loan before (Panel B). Loan receipt per business can be interpreted as the percentage of employer businesses receiving PPP loans in each zip code, but it is important to note that not all employer businesses qualify for loans nor necessarily want loans, and thus we do not expect the measure to ever reach 1. Both figures exhibit a positive relationship between loan receipt per employer business and the minority share of the population across zip codes in the United States. ${ }^{8}$ For first draw loans, moving from the first quartile in minority share of the population (16 percent minority) to the third quartile (59 percent minority), loan receipt increases from 0.055 to 0.088 PPP loans to employer businesses per employer business in the zip code. Figure 2 shows that there was already a positive, but weaker relationship in round 2 (Panel B). However, the first round shows the opposite pattern (Panel A): There is a strong negative relationship between loan receipt and minority population share. Moving from the first quartile to the third quartile in minority share is associated with a decrease from 0.17 to 0.13 PPP loans per employer business.

\footnotetext{
${ }^{8}$ In all regressions shown in figures in this paper as dashed lines, the coefficients of the linear and squared terms of the minority share are jointly significantly different from zero at the $95 \%$ confidence level. This also holds when we run unweighted regressions.
} 
The disbursement of PPP funds across communities by minority share might differ when measured by loan amounts instead of number of loans. Figure 3 display average loan amounts to employer businesses per business employee by minority share in the population at the zip code level in the third round (first and second draw). Loan amounts per employee can be interpreted as the unconditional average PPP loan amount per employee in a zip code but not all employer businesses qualify and not all employees qualify for loans, and thus we do not expect the measure to reach the maximum amount per employee. We find an upward relationship of PPP loan amounts per employee with minority share for first draw loans and a flat association for second draw loans. For first draw loans, moving from the first to the third quartile in minority share is associated with an increase from \$349 to \$775 in average loan amount per employee. Figure 4 shows that there was already a positive, but less pronounced relationship in the second round, but a negative relationship in the first round, similar to what we found for loan numbers.

The minority share of businesses in a community may be different from the minority share of the population. Therefore, we turn to analyzing the relationship between PPP loans per employer business and the minority share of businesses in counties. The relationship for the third PPP round (first and second draw) is displayed in Figure 5 and for the first two rounds in Figure 6. We combine counties with minority shares of businesses equal to or larger than $45 \%$ into one column because the number of counties in $5 \%$ bins with higher minority shares of businesses drops below 5. Similar to our findings using the minority share of the population, we find positive relationships between loan receipt and minority business share in the third round in 2021 (first and second draw) as well as the second round in 2020, but a negative relationship in the first round 2020.

\subsection{Nonemployer Businesses}


The 2021 reboot of the PPP (third round) emphasized supporting sole proprietorships, selfemployed individuals and independent contractors with no employees. Therefore, we separately analyze nonemployer businesses next (at the county level due to data availability). Figure 7 reveals that the number of PPP loans to nonemployer businesses per nonemployer business in the county has a strong positive relationship with minority share of the population, both for the first and second draw. Different from what we find for employer businesses the positive relationship is also very strong for second draw loans, which might reflect more continuing struggles to find work among minority independent contractors and small sole proprietors in the pandemic in comparison to minority-owned stores, restaurants and other employer businesses. The column for the $75-80 \%$ bin of minority share of the population is an outlier. There are 20 counties in this bin, but the weighted average is dominated by Hinds County, Mississippi, which is by far the most populous county in this bin with 240,000 inhabitants. In general, bins in the right half of the county-level charts only contain comparably small numbers of counties (minimum 5), so conclusions should be drawn from the dashed weighted regression curves rather than from individual columns at the right side of the chart.

Figure 8 shows that the association between nonemployer loans per nonemployer business in the county was essentially flat in the second round, but clearly negative in the first round. This pattern of results is similar to what we found for employer businesses. ${ }^{9}$ The PPP evolved over time not just for employer businesses but also for much smaller nonemployer businesses. The column corresponding to the $80 \%-85 \%$ of the minority share is again an outlier: its 19 counties are dominated by Honolulu, Hawaii, which is by far the most populous county in this bin.

\footnotetext{
${ }^{9}$ Tables A1 and A2 in the Appendix combine employer and nonemployer businesses and present the total number of loans to all businesses per business at the county level. The pattern of relationships with minority share in the different rounds of the PPP is the same.
} 
Finally, we analyze PPP loan amounts to nonemployer businesses per nonemployer business in the county. In this case, we view the owner's job as the sole worker for normalization, and as noted above the use of all nonemployer business entities in the county is likely to be over inclusive. The results appear in Figures 9 and 10. We find a similar pattern: The relationship between loan amounts to nonemployer businesses with minority share is strongly positive in 2021 (first and second draw), weaker positive in the second round in 2020, and strongly negative in the first round in 2020 .

\section{Discussion}

As COVID-19 cases began to rise sharply in the fall of 2020, the PPP was rebooted, and rebooted with an emphasis on helping eligible borrowers in underserved and disadvantaged communities. The program ran from January 2021 to May 2021 handing out 6.7 million loans for a total of \$278 billion. Analyzing administrative microdata on the universe of PPP loans for this third and final round, we find substantial evidence that the program disbursed funds to minority communities in 2021. The relationship between loan receipt or amounts and minority share of the population is generally strong and positive across all measures used. The various cuts of the data reveal interesting and important findings. The positive relationship is stronger for first loan draws than for second loan draws for employer businesses. For both first and second draw loans, demand for PPP loans is likely to be higher in disadvantaged communities as small business continued to struggle, and the major structural changes to the program are likely to have increased the supply of loans to those same communities. But, eligibility for a second draw loan depended on receipt of a loan in 2020 when relatively fewer businesses in communities with higher minority shares 
were served. The lack of a strong positive relationship in second draw loans generates some concerns over the persistence of inequities in the program from the early stages of the PPP rollout.

The shift in PPP loan provision from employer businesses to nonemployer businesses in 2021 and differences between the two types of businesses are important. Equitable disbursement of employer business loans has implications for community impacts on not only owners but also jobs and broader economic activity but equitable loans to nonemployer businesses also have important implications for the owner. We find strong positive relationships between loan receipt or amounts and minority share for first draw loans to both types of businesses, but concerning second draw loans, there is a strong positive relationship only for nonemployer businesses. Overall, our findings suggest that PPP funds in the third round in 2021 were distributed, as intended, to minority owners of businesses of all sizes and their employees.

There is a clear evolution of PPP funding to minority communities across subsequent rounds of the PPP from a negative relationship in the first round in 2020 to the strong positive relationship in the rebooted program (i.e. third round) in 2021. Why did the slope of the relationship change over time? Applying for PPP loans very early in the pandemic favored having long established relationships with banks which minority businesses were less likely to have (Mills et al. 2020). Minority-owned businesses also tend to be smaller than non-minority-owned businesses (U.S. Census Bureau 2016; Fairlie and Robb 2008), and smaller businesses often took longer to complete required paperwork due to a lack of resources and experience. ${ }^{10}$ Importantly, fintech lenders became increasingly involved over time, and these lenders often served minority businesses (Liu and Parilla 2020, Fei and Yang 2021, Howell et al., 2021). For example, BSD

\footnotetext{
${ }^{10}$ A large share of early funds flowed through smaller community banks which were often in rural areas because these banks were nimbler at accessing the aid (Grotto et al. 2020). In the second round larger banks with more urban and racially diverse customer bases caught up.
} 
Capital and Itria Ventures were almost absent in the first round in 2020 but moved up to the top 10 lenders by number of PPP loans in 2021 (Table 1). In 2021, the SBA also explicitly promoted involvement of Community Development Financial Institutions (CDFIs), for example by providing a head start for applications through CDFIs at the beginning of the third round in January 2021. The non-profit CDFI Prestamos started at rank 4274 of lenders by PPP loans in the first round in 2020, moved up to rank 325 in the second round and became the number one lender in the third round and thereby also overall (Table 1). Prestamos especially targeted Latinx business owners. Provisions such as the 14-day exclusivity application period for businesses with fewer than 20 employees in February 2021 may also have helped to bring PPP loans to disadvantaged small businesses. More research is needed to assess the relative importance of these potential explanations for the change in the disbursement of PPP loans to minority communities over time. It is also unclear how severe the short-term and long-term consequences of the delay in receiving loans were for minority businesses and communities.

Our analysis of administrative data on PPP loans suggests a few additional areas for further research. First, the patterns that we find for loan receipt by minority share of communities are mostly consistent with recent studies that use proxies for business owner race and ethnicity such as Yelp listed restaurants, and names and locations (e.g. Fei and Yang 2021; Howell et al. 2021). More research linking data with information on the race and ethnicity of owners to loan data would be useful. Second, the PPP loan microdata could add additional information such as which application form was used, which would allow a cleaner separation of owner jobs from employees. The SBA could also provide information on their distinctions by bank type used in their reports which would be useful for analyzing the data more carefully by type (e.g. fintechs, traditional banks, or CDFIs). Third, using linked longitudinal data it would be interesting to examine which 
businesses and circumstances led to second draw loans in 2021. Many minority businesses might have been reluctant to apply for PPP loans because of uncertainty over future revenues due to entering the pandemic in a weakened position (Mills and Battisto 2020). More research is needed on the dynamics of PPP receipt over the three rounds of funding. 


\section{References}

Atkins, Rachel, Lisa D. Cook, and Robert Seamans. 2021. "Discrimination in Lending? Evidence from the Paycheck Protection Program,” Small Business Economics, https://doi.org/10.1007/s11187-021-00533-1.

Centers for Disease Control and Prevention. 2021. "COVID Data Tracker,” https://covid.cdc.gov/covid-data-tracker/\#trends_dailycases.

Chernenko, Sergey and David S. Scharfstein. 2021. "Racial Disparities in the Paycheck Protection Program,” SSRN Working Paper 3907575.

Couch, Kenneth A., Robert W. Fairlie, and Huanan Xu. 2020. "Early Evidence of the Impacts of COVID-19 on Minority Unemployment,” Journal of Public Economics 192: 104287.

Cowan, Benjamin W. 2020. "Short-run Effects of COVID-19 on US Worker Transitions," National Bureau of Economic Research Working Paper No. w27315.

Darity, William, and Raffi Garcia. 2022. “Self-Reporting Race in Small Business Loan Applications: A Game-Theoretic Analysis of Evidence from PPP Loans in Durham, NC,” Duke University Working Paper.

Fairlie, Robert. 2020. "The Impact of COVID-19 on Small Business Owners: Evidence from the First Three Months after Widespread Social-distancing Restrictions,” Journal of Economics \& Management Strategy 29(4): 727-740.

Fairlie, Robert W. and Frank M. Fossen. 2021. "Did the Paycheck Protection Program and Economic Injury Disaster Loan Program Get Disbursed to Minority Communities in the Early Stages of COVID-19?” Small Business Economics, https://doi.org/10.1007/s11187-021-00501-9.

Fairlie, Robert W. and Alicia M. Robb. 2008. Race and Entrepreneurial Success: Black-, Asianand White-Owned Businesses in the United States, Cambridge: MIT Press.

Fei, Celine Yue and Keer Yang. 2021. "Fintech and Racial Barriers in Small Business Lending,” University of North Carolina at Chapel Hill Working Paper.

Grotto, Jason, Zachary R. Mider, and Cedric Sam. 2020. "White America Got a Head Start on Small-Business Virus Relief,” Bloomberg.

Howell, Sabrina T., Theresa Kuchler, David Snitkof, Johannes Stroebel, and Jun Wong. 2021. "Racial Disparities in Access to Small Business Credit: Evidence from the Paycheck Protection Program,” National Bureau of Economic Research Working Paper No. w29364.

Liu, Sifan and Joseph Parilla. 2020. "New Data Shows Small Businesses in Communities of Color Had Unequal Access to Federal COVID-19 Relief,” Brookings Institution Report.

Montenovo, Laura, Xuan Jiang, Felipe L. Rojas, Ian M. Schmutte, Kosali I. Simon, Bruce A. Weinberg, and Coady Wing. 2020. "Determinants of Disparities in Covid-19 Job Losses," National Bureau of Economic Research Working Paper No. w27132. 
Mills, Claire Kramer and Jessica Battisto. 2020. “Double Jeopardy: COVID-19’s Concentrated Health and Wealth Effects in Black Communities,” Federal Reserve Bank of New York.

Mills, Claire Kramer, Jessica Battisto, Mels de Zeeuw, Scott Lieberman, and Ann Marie Wiersch. 2020. Small Business Credit Survey, Federal Reserve Banks.

U.S. Census Bureau. 2016. "Survey of Business Owners (SBO) - Survey Results: 2012”

U.S. Congress. 2020. “Coronavirus Aid, Relief, and Economic Security Act,” https://www.congress.gov/116/bills/hr748/BILLS-116hr748enr.pdf.

U.S. Small Business Administration. 2021. "Biden Administration Takes Steps to Promote Equitable Access to SBA Relief,” https://www.sba.gov/funding-programs/loans/covid-19-reliefoptions/paycheck-protection-program/ppp-lender-information. 
Tables

Table 1: Main PPP Lenders

\begin{tabular}{|c|c|c|c|c|c|c|c|c|c|c|c|c|c|c|c|c|c|}
\hline \multirow[b]{2}{*}{ Lender Name } & \multicolumn{5}{|c|}{ All Rounds } & \multicolumn{3}{|c|}{ Round 1 (2020) } & \multicolumn{3}{|c|}{ Round 2 (2020) } & \multicolumn{3}{|c|}{ Round 3, $1^{\text {st }}$ Draw } & \multicolumn{3}{|c|}{ Round $3,2^{\text {nd }}$ Draw } \\
\hline & $\begin{array}{l}\text { Loans } \\
\text { Number } \\
\end{array}$ & $\begin{array}{l}\text { Loans } \\
\%\end{array}$ & $\begin{array}{l}\text { Amt. } \\
\text { Mil. \$ }\end{array}$ & $\begin{array}{l}\text { Amt. } \\
\%\end{array}$ & Rank & $\begin{array}{l}\text { Loans } \\
\%\end{array}$ & $\begin{array}{l}\text { Amt. } \\
\%\end{array}$ & Rank & $\begin{array}{l}\text { Loans } \\
\%\end{array}$ & $\begin{array}{l}\text { Amt. } \\
\%\end{array}$ & Rank & $\begin{array}{l}\text { Loans } \\
\%\end{array}$ & $\begin{array}{l}\text { Amt. } \\
\%\end{array}$ & Rank & $\begin{array}{l}\text { Loans } \\
\%\end{array}$ & $\begin{array}{l}\text { Amt. } \\
\%\end{array}$ & Rank \\
\hline Prestamos & 495,468 & 4.37 & 76,957 & 1.04 & 1 & 0.00 & 0.00 & 4274 & 0.03 & 0.01 & 325 & 12.88 & 11.47 & 1 & 0.66 & 0.17 & 27 \\
\hline Cross River Bank & 472,780 & 4.17 & 124,865 & 1.68 & 2 & 0.86 & 0.33 & 12 & 5.28 & 2.76 & 4 & 5.45 & 6.13 & 5 & 2.99 & 1.27 & 6 \\
\hline Capital Plus Financial & 463,563 & 4.09 & 74,178 & 1.00 & 3 & 0.00 & 0.00 & NA & 0.00 & 0.00 & NA & 10.92 & 10.35 & 2 & 2.13 & 0.41 & 9 \\
\hline Bank of America & 462,981 & 4.08 & 321,076 & 4.33 & 4 & 0.58 & 1.18 & 24 & 9.37 & 10.87 & 1 & 0.36 & 0.80 & 22 & 4.68 & 4.08 & 2 \\
\hline Harvest Small Bus. Fin. & 432,778 & 3.82 & 85,318 & 1.15 & 5 & 0.01 & 0.03 & 2000 & 0.15 & 0.58 & 65 & 7.76 & 7.33 & 3 & 5.02 & 1.36 & 1 \\
\hline JPMorgan Chase Bank & 414,413 & 3.65 & 392,196 & 5.29 & 6 & 1.66 & 3.87 & 6 & 7.04 & 8.70 & 2 & 0.95 & 1.83 & 11 & 4.32 & 5.35 & 3 \\
\hline Benworth Capital & 331,258 & 2.92 & 45,607 & 0.61 & 7 & 0.00 & 0.00 & NA & 0.02 & 0.01 & 516 & 7.15 & 5.84 & 4 & 2.36 & 0.41 & 8 \\
\hline Customers Bank & 284,436 & 2.51 & 69,500 & 0.94 & 8 & 0.07 & 0.12 & 219 & 2.00 & 1.17 & 9 & 3.56 & 3.24 & 9 & 3.06 & 1.19 & 5 \\
\hline Fountainhead SBF & 272,561 & 2.40 & 41,183 & 0.56 & 9 & 0.00 & 0.01 & 2390 & 0.08 & 0.18 & 125 & 5.18 & 3.95 & 6 & 2.79 & 0.62 & 7 \\
\hline Wells Fargo Bank & 266,601 & 2.35 & 127,974 & 1.73 & 10 & 0.06 & 0.03 & 251 & 5.44 & 5.08 & 3 & 0.82 & 1.10 & 13 & 1.98 & 1.34 & 10 \\
\hline BSD Capital & 249,089 & 2.20 & 47,913 & 0.65 & 11 & 0.00 & 0.00 & 2536 & 0.10 & 0.09 & 96 & 4.27 & 4.54 & 7 & 3.12 & 0.86 & 4 \\
\hline Kabbage & 178,128 & 1.57 & 32,498 & 0.44 & 12 & 0.00 & 0.00 & NA & 4.84 & 1.62 & 5 & 0.00 & 0.00 & NA & 0.66 & 0.13 & 28 \\
\hline Itria Ventures & 176,747 & 1.56 & 48,850 & 0.66 & 13 & 0.00 & 0.00 & NA & 0.09 & 0.07 & 113 & 3.58 & 3.98 & 8 & 1.48 & 1.11 & 13 \\
\hline U.S. Bank & 167,288 & 1.48 & 99,863 & 1.35 & 14 & 1.12 & 0.73 & 10 & 2.56 & 2.61 & 7 & 0.58 & 0.78 & 15 & 1.57 & 1.27 & 12 \\
\hline Celtic Bank & 164,423 & 1.45 & 43,788 & 0.59 & 15 & 0.07 & 0.04 & 243 & 4.36 & 1.96 & 6 & 0.00 & 0.00 & NA & 0.71 & 0.33 & 25 \\
\hline TD Bank & 128,541 & 1.13 & 109,735 & 1.48 & 16 & 1.62 & 1.74 & 7 & 1.75 & 1.35 & 10 & 0.25 & 0.43 & 29 & 1.30 & 1.56 & 14 \\
\hline WebBank & 117,481 & 1.04 & 30,903 & 0.42 & 17 & 0.24 & 0.06 & 64 & 2.15 & 1.03 & 8 & 0.46 & 0.36 & 17 & 0.92 & 0.39 & 20 \\
\hline Truist Bank & 111,747 & 0.99 & 147,686 & 1.99 & 18 & 1.89 & 2.75 & 3 & 1.42 & 1.81 & 11 & 0.24 & 0.41 & 30 & 0.96 & 1.54 & 19 \\
\hline Readycap Lending & 110,794 & 0.98 & 48,910 & 0.66 & 19 & 2.22 & 0.85 & 1 & 0.00 & 0.01 & 2132 & 1.16 & 1.42 & 10 & 1.20 & 0.74 & 15 \\
\hline PNC Bank & 109,859 & 0.97 & 156,177 & 2.11 & 20 & 1.27 & 2.73 & 9 & 1.42 & 1.96 & 12 & 0.37 & 0.63 & 21 & 1.07 & 1.79 & 16 \\
\hline
\end{tabular}

Notes: The ranks refer to the number of loans made in each round. Only the 20 lenders providing the largest numbers of loans overall are shown. PPP loans to nonprofit businesses and businesses with nonclassifiable industry are excluded. 
Table 2: Descriptive Statistics at the Local Level

\begin{tabular}{|c|c|c|c|c|c|c|c|c|}
\hline & \multicolumn{2}{|c|}{ Round 1 (2020) } & \multicolumn{2}{|c|}{ Round 2 (2020) } & \multicolumn{2}{|c|}{$\begin{array}{l}\text { Round } 3 \text { (2021) } \\
1^{\text {st }} \text { Draw }\end{array}$} & \multicolumn{2}{|c|}{$\begin{array}{l}\text { Round } 3(2021) \text {, } \\
2^{\text {nd }} \text { Draw }\end{array}$} \\
\hline & Mean & $\mathrm{N}$ & Mean & $\mathrm{N}$ & Mean & $\mathrm{N}$ & Mean & $\mathrm{N}$ \\
\hline $\begin{array}{l}\text { PPP number of loans to employer businesses per employer } \\
\text { business in zip code } \\
\text { PPP unconditional average loan amount to employer }\end{array}$ & 0.143 & 31952 & 0.279 & 31952 & 0.077 & 31952 & 0.193 & 31952 \\
\hline businesses per employee in zip code & 2406 & 30356 & 1669 & 30356 & 257 & 30356 & 1659 & 30356 \\
\hline $\begin{array}{l}\text { PPP number of loans to nonemployer businesses per } \\
\text { nonemployer business in county }\end{array}$ & 0.0027 & 3137 & 0.0298 & 3137 & 0.1178 & 3137 & 0.0367 & 3137 \\
\hline $\begin{array}{l}\text { PPP unconditional average loan amount to nonemployer } \\
\text { businesses per nonemployer business in county }\end{array}$ & 39 & 3137 & 327 & 3137 & 1660 & 3137 & 506 & 3137 \\
\hline PPP number of loans to all businesses per business in county & 0.043 & 3137 & 0.089 & 3137 & 0.100 & 3137 & 0.076 & 3137 \\
\hline Minority share of the population (zip code) & 0.389 & 32670 & 0.389 & 32670 & 0.389 & 32670 & 0.389 & 32670 \\
\hline Minority share of the population (county) & 0.389 & 3142 & 0.389 & 3142 & 0.389 & 3142 & 0.389 & 3142 \\
\hline Min. share of employer businesses (county) & 0.180 & 1031 & 0.180 & 1031 & 0.180 & 1031 & 0.180 & 1031 \\
\hline
\end{tabular}

businesses exclude agricultural businesses. 
Table 3: Distribution of PPP Loan Amounts to Employer and Nonemployer Businesses

\begin{tabular}{|c|c|c|c|c|}
\hline & \multirow[t]{2}{*}{ Round 1 (2020) } & \multirow[t]{2}{*}{ Round 2 (2020) } & \multicolumn{2}{|c|}{ Round 3 (2021) } \\
\hline & & & $1^{\text {st }}$ Draw & $2^{\text {nd }}$ Draw \\
\hline \multicolumn{5}{|c|}{ PPP Loan Amounts to Employer Businesses: } \\
\hline Mean & 200,511 & 70,263 & 33,289 & 102,133 \\
\hline Std. dev. & 518,568 & 239,892 & 162,035 & 210,260 \\
\hline $1^{\text {st }}$ quartile & 25,000 & 11,100 & 7,386 & 17,710 \\
\hline Median & 61,200 & 23,008 & 16,036 & 37,813 \\
\hline $3^{\text {rd }}$ quartile & 161,100 & 57,500 & 21,285 & 95,020 \\
\hline Number of loans & $1,465,974$ & $2,492,018$ & 598,387 & $1,810,632$ \\
\hline \multicolumn{5}{|c|}{ PPP Loan Amounts to Nonemployer Businesses: } \\
\hline Mean & 14,400 & 11,194 & 14,186 & 13,736 \\
\hline Std. dev. & 45,099 & 14,603 & 7,325 & 8,513 \\
\hline $1^{\text {st }}$ quartile & 5,800 & 4,100 & 7,082 & 6,426 \\
\hline Median & 10,500 & 8,723 & 17,708 & 14,747 \\
\hline $3^{\text {rd }}$ quartile & 20,000 & 18,500 & 20,832 & 20,833 \\
\hline Number of loans & 67,241 & 804,083 & $3,095,717$ & $1,006,372$ \\
\hline
\end{tabular}


Figure 1: PPP Number of Loans to Employer Businesses per Employer Business in Zip Code by Minority Share in 2021

Panel A: First Draw

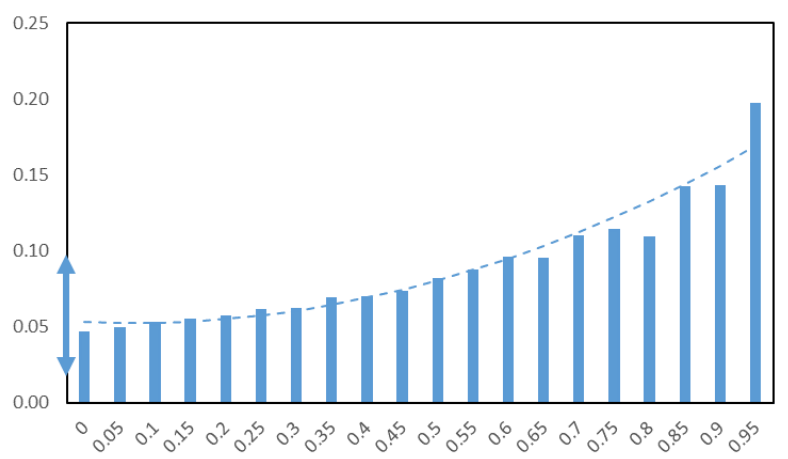

Panel B: Second Draw

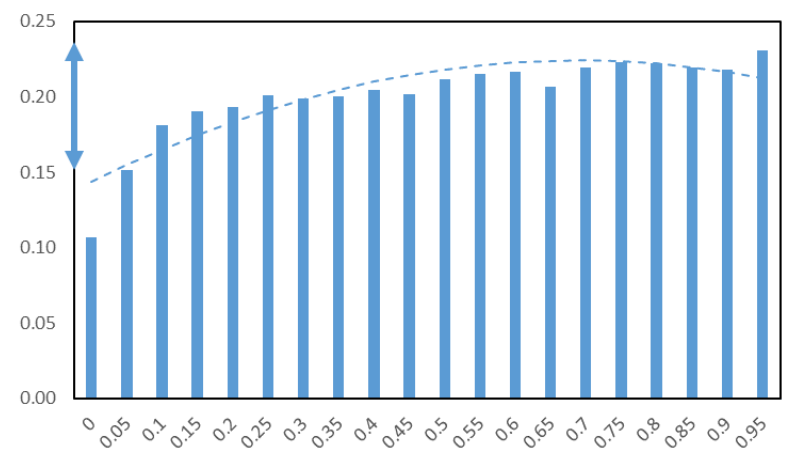

Notes: Mean numbers of first and second draw PPP loans to employer businesses in 2021 (Round 3) per employer business in zip codes by minority share of the population, weighted by population. The dashed lines are from quadratic regressions at the county level. The double arrow on the Y-axis indicates the median $\pm 1 / 2$ standard deviation.

Figure 2: PPP Number of Loans to Employer Businesses per Employer Business in Zip Code by Minority Share in 2020

Panel A: First Round

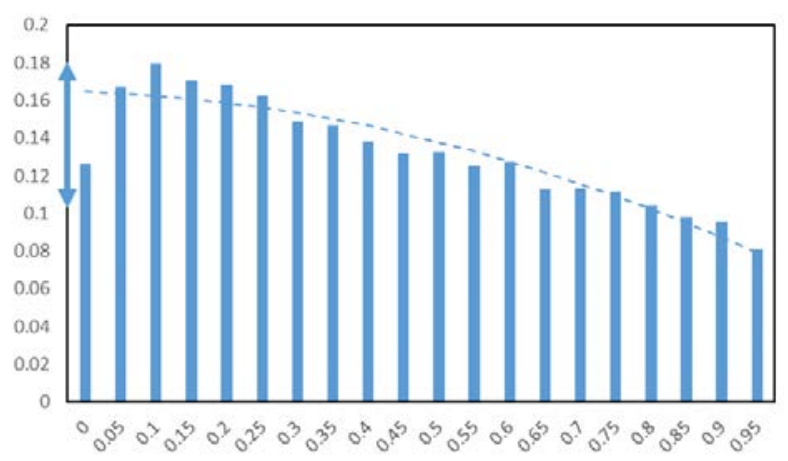

Panel B: Second Round

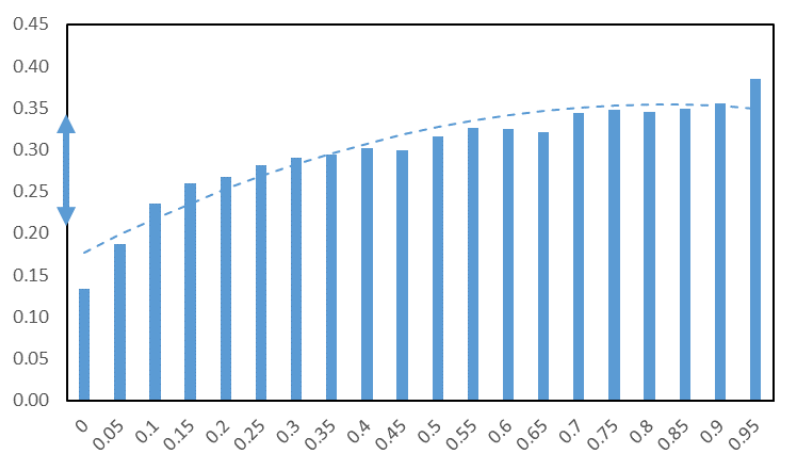

Notes: Mean numbers of PPP loans to employer businesses in 2020 (Rounds 1 and 2) per employer business in zip codes by minority share of the population, weighted by population. The dashed lines are from quadratic regressions at the county level. The double arrow on the Y-axis indicates the median $\pm 1 / 2$ standard deviation. 
Figure 3: PPP Loan Amounts to Employer Businesses per Employee in Zip Code by Minority Share in 2021

Panel A: First Draw

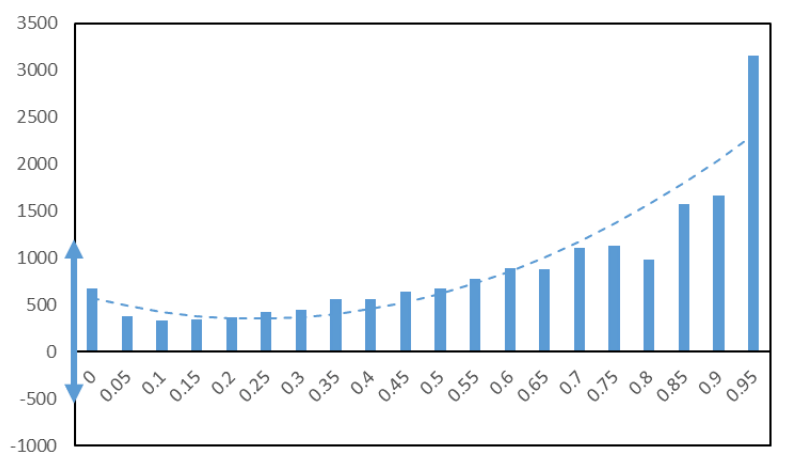

Panel B: Second Draw

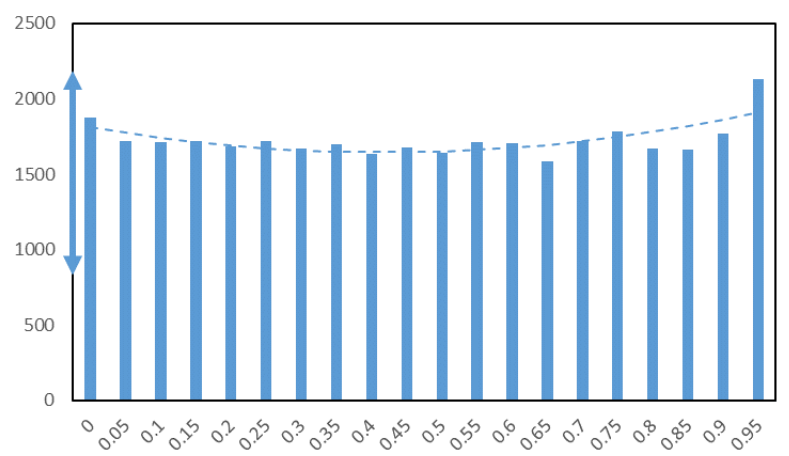

Notes: Unconditional mean amounts of first and second draw PPP loans to employer businesses in 2021 (Round 3) per employee in zip codes by minority share of the population, weighted by population. The dashed lines are from quadratic regressions at the county level. The double arrow on the $\mathrm{Y}$-axis indicates the median $\pm 1 / 2$ standard deviation. Excluding agricultural businesses.

Figure 4: PPP Loan Amounts to Employer Businesses per Employee in Zip Code by Minority Share in 2020

\section{Panel A: First Round}

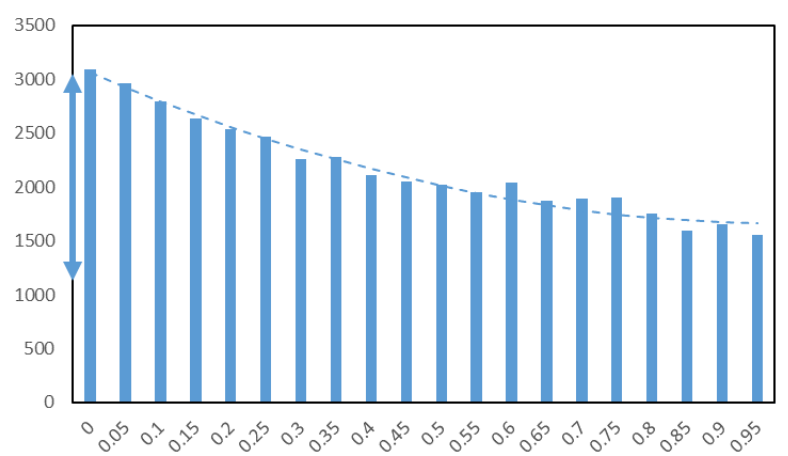

Panel B: Second Round

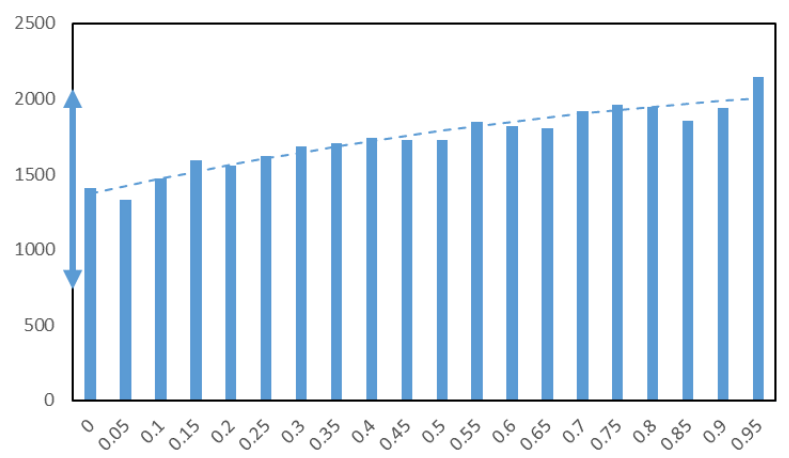

Notes: Unconditional mean amounts of PPP loans to employer businesses in 2020 (Rounds 1 and 2) per employee in zip codes by minority share of the population, weighted by population. The dashed lines are from quadratic regressions at the county level. The double arrow on the Y-axis indicates the median $\pm 1 / 2$ standard deviation. Excluding agricultural businesses. 
Figure 5: PPP Number of Loans to Employer Businesses per Employer Business in County by Minority Share of Businesses in 2021

Panel A: First Draw

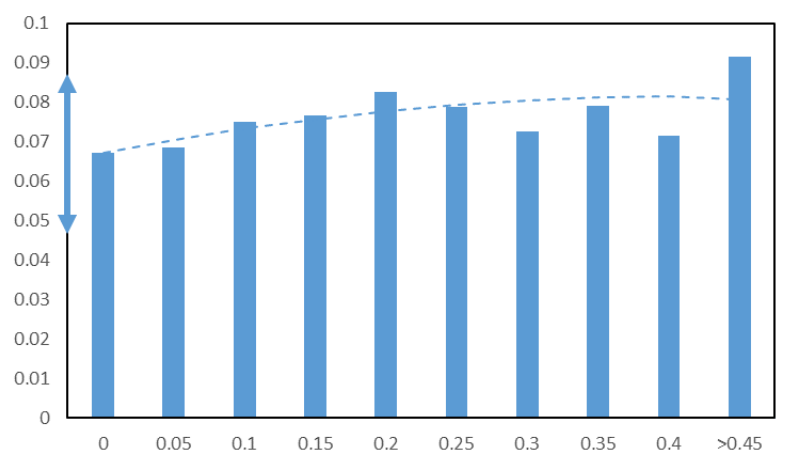

Panel B: Second Draw

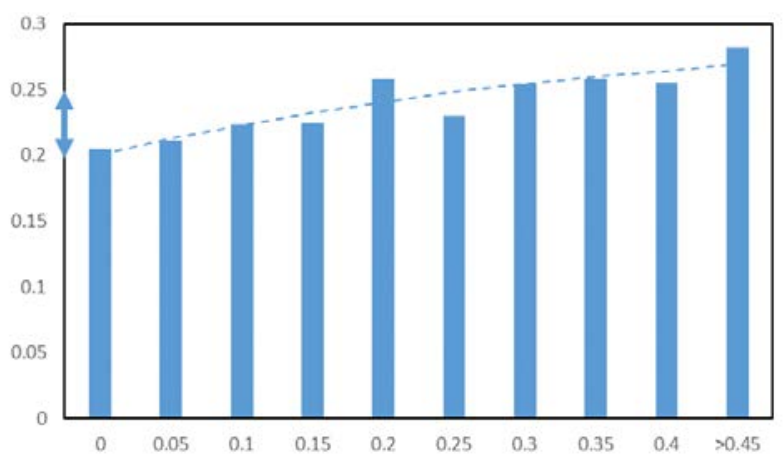

Notes: Mean numbers of first and second draw PPP loans to employer businesses in 2021 (Round 3) per employer business in counties by minority share of businesses, weighted by population. The dashed lines are from quadratic regressions at the county level. The double arrow on the Y-axis indicates the median $\pm 1 / 2$ standard deviation.

Figure 6: PPP Number of Loans to Employer Businesses per Employer Business in County by Minority Share of Businesses in 2020

\section{Panel A: First Round}

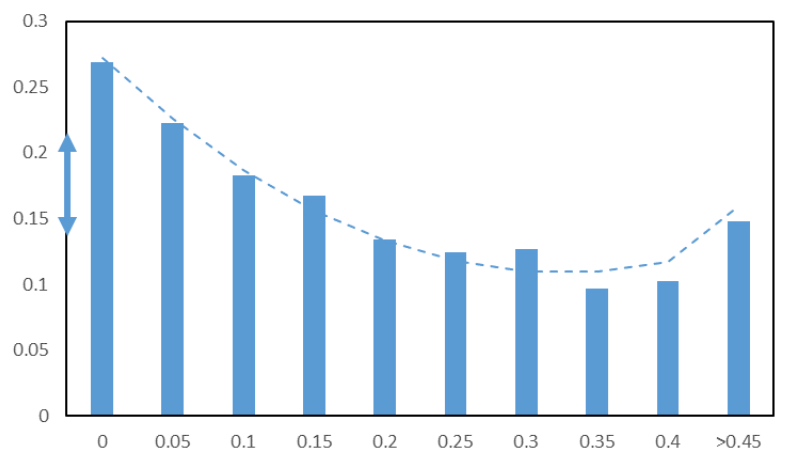

Panel B: Second Round

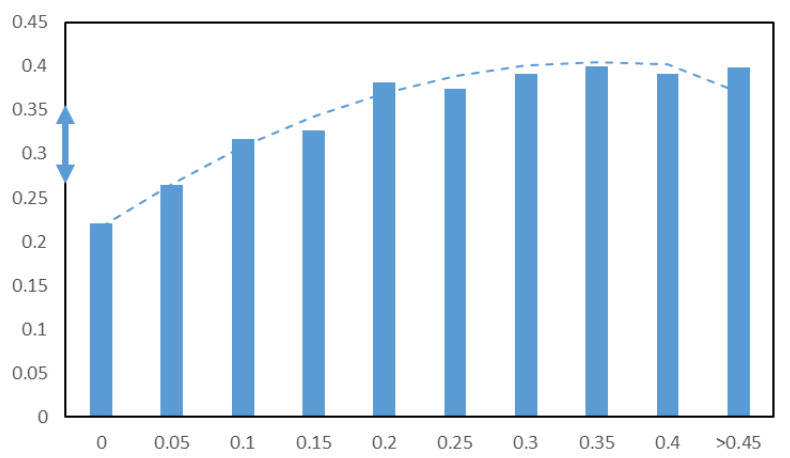

Notes: Mean numbers of PPP loans to employer businesses in 2020 (Rounds 1 and 2) per employer business in counties by minority share of businesses, weighted by population. The dashed lines are from quadratic regressions at the county level. The double arrow on the $\mathrm{Y}$-axis indicates the median $\pm 1 / 2$ standard deviation. 
Figure 7: PPP Number of Loans to Nonemployer Businesses per Nonemployer Business in County by Minority Share in 2021

Panel A: First Draw

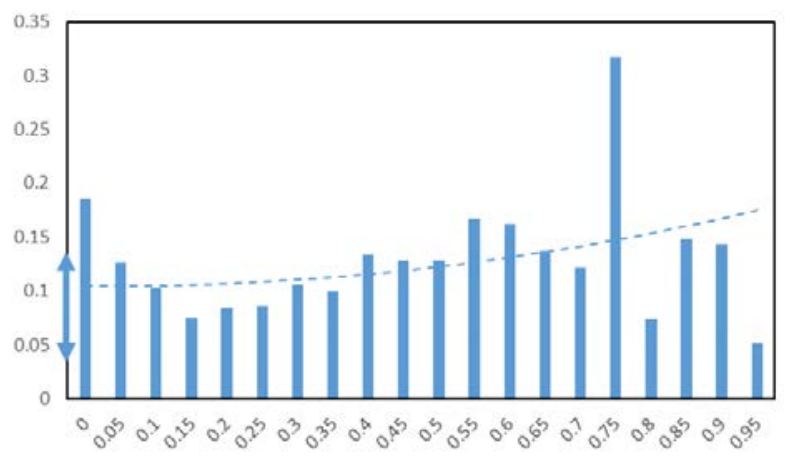

Panel B: Second Draw

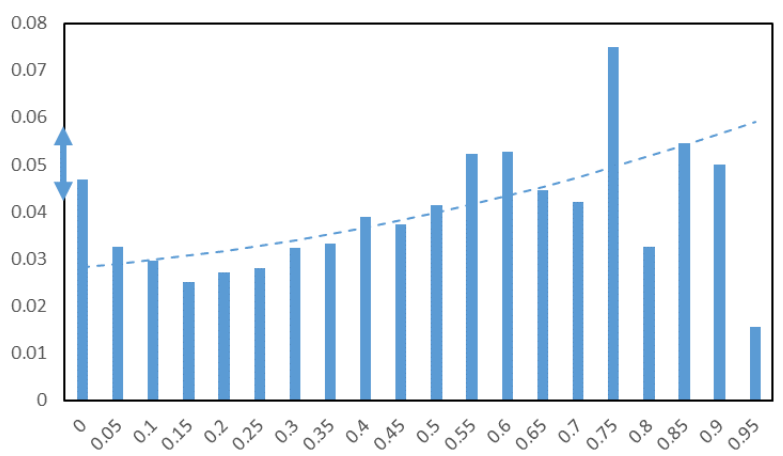

Notes: Mean numbers of first and second draw PPP loans to nonemployer businesses in 2021 (Round 3) per nonemployer business (owner job) in counties by minority share of the population, weighted by population. The dashed lines are from quadratic regressions at the county level. The double arrow on the Y-axis indicates the median $\pm 1 / 2$ standard deviation. Excluding agricultural businesses.

Figure 8: PPP Number of Loans to Nonemployer Businesses per Nonemployer Business in County by Minority Share in 2020

\section{Panel A: First Round}

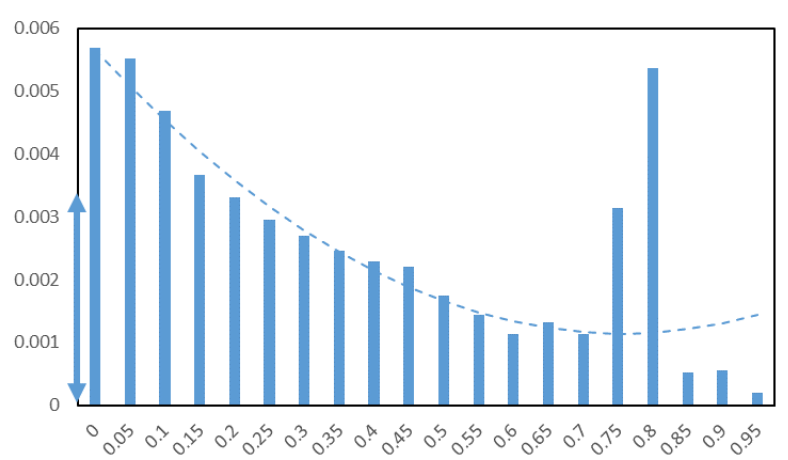

Panel B: Second Round

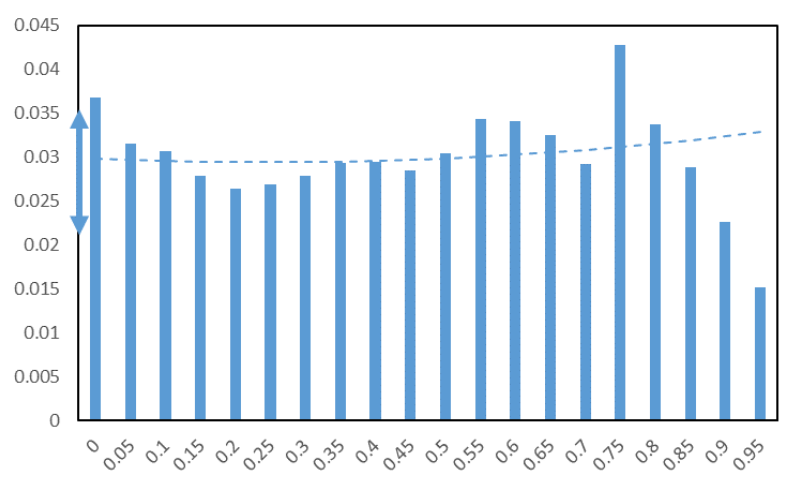

Notes: Mean numbers of PPP loans to nonemployer businesses in 2020 (Rounds 1 and 2) per nonemployer business (owner job) in counties by minority share of the population, weighted by population. The dashed lines are from quadratic regressions at the county level. The double arrow on the $\mathrm{Y}$-axis indicates the median $\pm 1 / 2$ standard deviation. 
Figure 9: PPP Loan Amounts to Nonemployer Businesses per Nonemployer Business in County by Minority Share in 2021

\section{Panel A: First Draw}

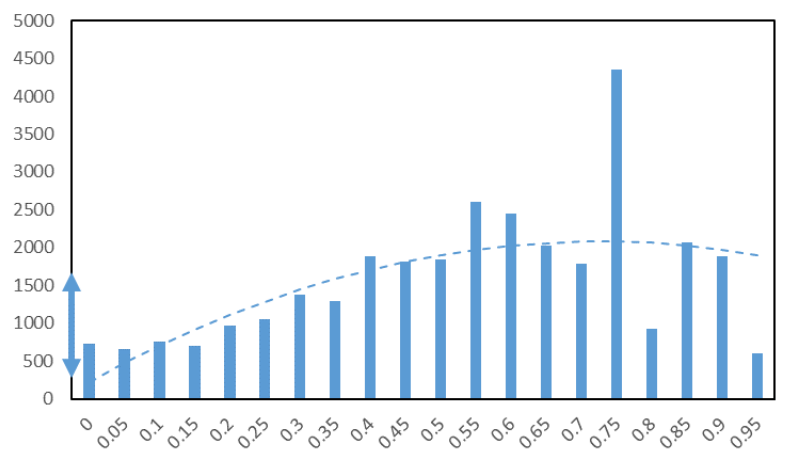

\section{Panel B: Second Draw}

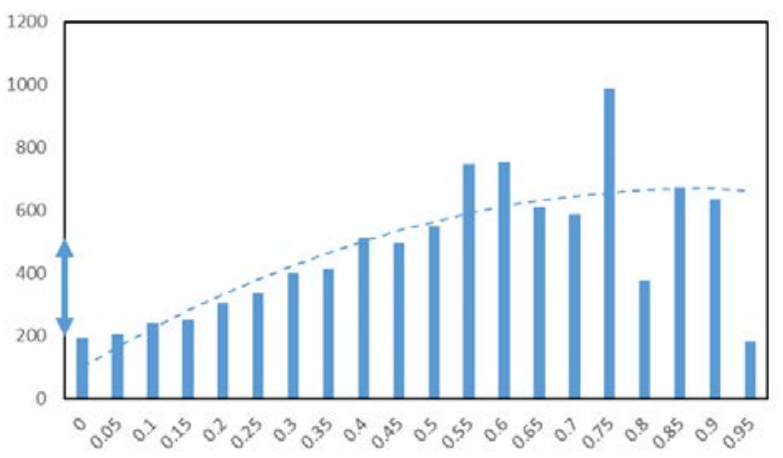

Notes: Unconditional mean amounts of first and second draw PPP loans to nonemployer businesses in 2021 (Round 3) per nonemployer business (owner job) in counties by minority share of the population, weighted by population. The dashed lines are from quadratic regressions at the county level. The double arrow on the $\mathrm{Y}$-axis indicates the median $\pm 1 / 2$ standard deviation. Excluding agricultural businesses.

Figure 10: PPP Loan Amounts to Nonemployer Businesses per Nonemployer Business in County by Minority Share in 2020

\section{Panel A: First Round}

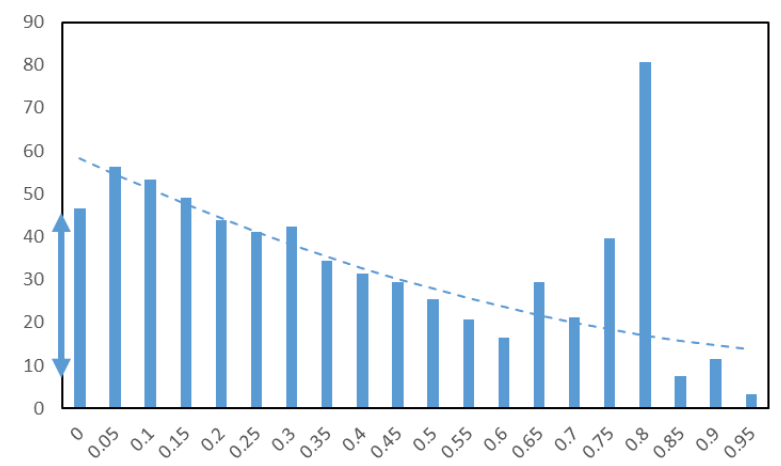

Panel B: Second Round

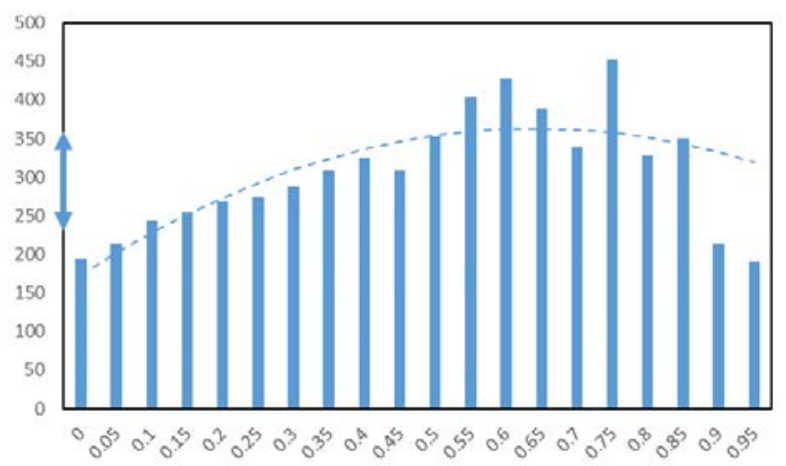

Notes: Unconditional mean amounts of PPP loans to nonemployer businesses in 2020 (Rounds 1 and 2) per nonemployer business (owner job) in counties by minority share of the population, weighted by population. The dashed lines are from quadratic regressions at the county level. The double arrow on the Y-axis indicates the median $\pm 1 / 2$ standard deviation. Excluding agricultural businesses. 


\section{Appendix}

Table A1: Distribution of PPP Loan Amounts to All Businesses

\begin{tabular}{|c|c|c|c|c|}
\hline & \multirow[t]{2}{*}{ Round 1 (2020) } & \multirow[t]{2}{*}{ Round 2 (2020) } & \multicolumn{2}{|c|}{ Round 3 (2021) } \\
\hline & & & $1^{\text {st }}$ Draw & $2^{\text {nd }}$ Draw \\
\hline Mean & 192,349 & 55,853 & 17,280 & 70,553 \\
\hline Std. dev. & 508,587 & 210,249 & 65,935 & 173,884 \\
\hline $1^{\text {st }}$ quartile & 21,870 & 8,292 & 7,141 & 11,666 \\
\hline Median & 56,600 & 19,300 & 17,500 & 20,833 \\
\hline $3^{\text {rd }}$ quartile & 152,500 & 41,668 & 20,832 & 55,252 \\
\hline Number of loans & $1,533,215$ & $3,296,101$ & $3,694,104$ & $2,817,004$ \\
\hline
\end{tabular}

Notes: PPP loans to nonprofit businesses and businesses with nonclassifiable industry are excluded.

Figure A1: PPP Number of Loans to All Businesses per Business in County by Minority Share in 2021

Panel A: First Draw

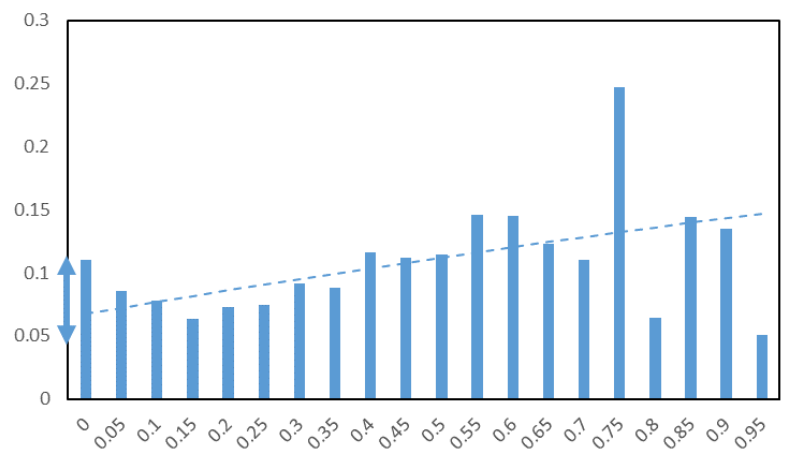

Panel B: Second Draw

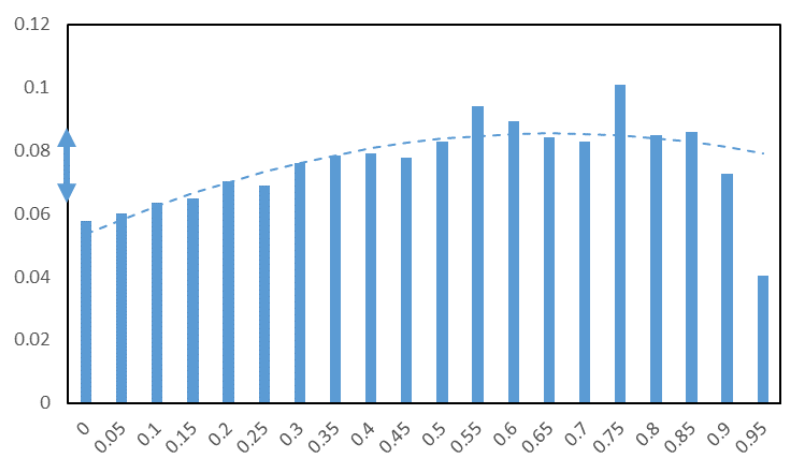

Notes: Mean numbers of first and second draw PPP loans to all businesses in 2021 (Round 3) per business in counties by minority share of the population, weighted by population. The dashed lines are from quadratic regressions at the county level. The double arrow on the $\mathrm{Y}$-axis indicates the median $\pm 1 / 2$ standard deviation. 
Figure A2: PPP Number of Loans to All Businesses per Business in County by Minority Share in 2020

Panel A: First Round

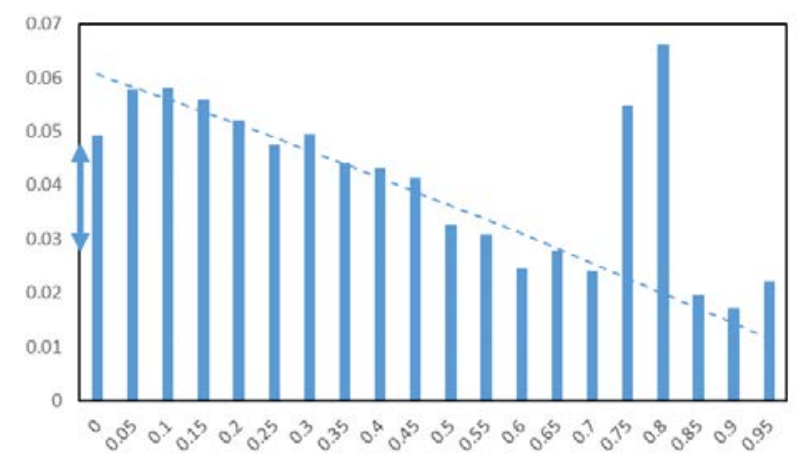

Panel B: Second Round

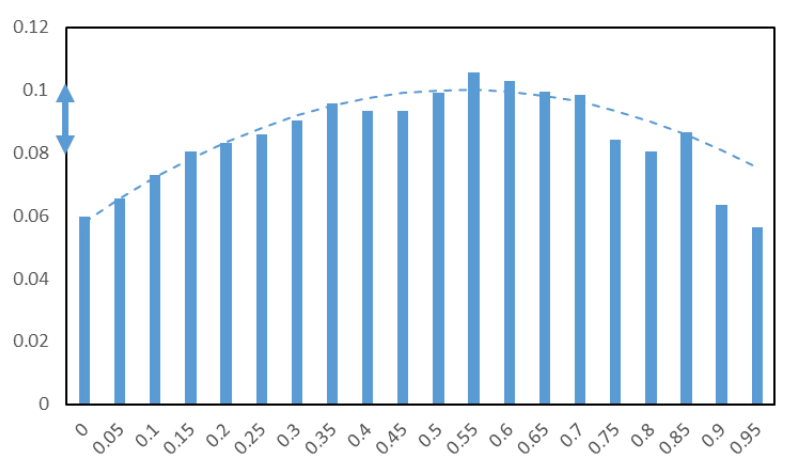

Notes: Mean numbers of PPP loans to all businesses in 2020 (Rounds 1 and 2) per business in counties by minority share of the population, weighted by population. The dashed lines are from quadratic regressions at the county level. The double arrow on the $\mathrm{Y}$-axis indicates the median $\pm 1 / 2$ standard deviation. 